\section{THE ACCENTUAL SYSTEM \\ OF THAI POLYSYLLABIC WORDS}

\section{Udom Warotamasikkhadit $^{1}$}

\begin{abstract}
Many Thai grammarians seem to ignore intonational rhythms that exist in the pronunciation of Thai words. It is erroneous to think that Thai words are monotonous and without rhythms. The Thais have pronounced words with fixed pronunciation patterns for years but many grammarians and Thai scholars ignore them. At the moment pronunciation of the language is chaotic because many Thai people do not know how to pronounce Thai words. They often make the wrong cuts at morpheme or word boundaries. The Royal Institute rules for the pronunciation of Thai words concerning the gemination of the final consonant of a syllable with an inserted [a] in conjoining words, as found in the dictionary of the Royal Institute of B.E. 2525, must be held responsible for these problems. This paper points out the word rhythms of Thai as found in daily speech of the Thai people.
\end{abstract}

1 Professor Emeritus, Ramkhamhaeng University.

\section{Introduction}

At present, the pronunciation of Thai language is in a state of chaos. No one knows for sure how to pronounce certain words in the Thai language. If one looks through the Dictionary of the Royal Institute of B.E. 2525, one will find words with more than one pronunciation more often than one will find in an English, French, or German dictionary. Nowadays radio and television announcers often mispronounce words and are influential sources of mispronunciation. If you turn on two different radio stations, you will find two different pronunciations of the same word. It is very confusing for young children who must decide which one is correct. The Royal Institute of Thailand seems to compromise that two pronunciations are acceptable.

\section{The origin of the problems}

We cannot really blame the radio and television announcers for their mispronunciations. They have to take the oral diction examination administered by the Department of Public Relations and supervised by the Royal Institute of Thailand in order to acquire an announcer certificate. The Department of Public Relations of Thailand follows pronunciation rules written in the Dictionary of the Royal Institute of B.E. 2525 and usually invites representatives 
from the Royal Institute to be present during the oral diction examination. Thus, the Royal Institute of Thailand cannot avoid being blamed for causing the pronunciation chaos that is rampant in Thailand these days.

There are a number of reasons why people consider the Royal Institute to be the origin of the problems (Phasit Chitphasa 1998).

2.1 The pronunciation rules on page (7) of the Dictionary of the Royal Institute of B.E. 2525 (6th edition) says; "Conjoining Pali-Sanskrit words must be read according to the principles-i.e. the word final must be geminated together with an intruding /a/. The pronunciation of this type of words is provided, such as ทารุณกรรม [ทารุนนะกำ] [thaarunná $\mathrm{kam}$, สุขนาฏกรรม [สุกขะนาดตะกำ] [sụkkhạnâattạkam], รูปธรรม [รูบปะทำ] [rûuppatham] and another type that can be pronounced two ways -- i.e. the pronunciation according to the principles and the pronunciation according to popular usage, where the pronunciation according to the principles will come first, such as ประวัติศาสตร์ [ประหวัดติสาด, ประหวัดสาด] [prạạattịsạat, prawàtsàat], มัธยมศึกษา [มัดทะยมมะศึกษา, มัดทะยมศึกษา] [máttáyommásìksạa, máttáyomsł̣̣k sạa], อุดมการณ์ [อุดมมะกาน, อุดมกาน] [?ụdommákaan, Pụdomkaan]”.
This statement is incorrect on several counts. Firstly, some conjoining Thai words must be pronounced with the syllable final gemination plus an intruding $/ \mathrm{a} /$, such as กรมขุน [krommákhụn] 'the title of the prince of the fourth rank' (a Cambodian and a Thai word), ทุนทรัพย์ [thunnásáp] 'money invested; collateral or funds used as capital' (a Thai and a Sanskrit word), สรรพสิ่ง [sạpphá sì] 'all the things', (a Sanskrit and a Thai word), สักวัน [sákkàwan] 'even one day' (a Thai and a Thai word). Secondly, certain conjoining Pali-Sanskrit words are not pronounced with a syllable final gemination plus an intruding $/ \mathrm{a} /$, such as ชัยนาท [chaynâat] 'the name of a province in Central Thailand', ปทุมธานี [pạthumthaanii] 'the name of a province north of Bangkok', พิชิตมาร [phíchitmaan] 'one who conquered Mara, i.e. the Buddha' (a modified Sanskrit word (by changing a $/ \mathrm{v} /$ to $\mathrm{a} / \mathrm{ph} /$ ) and a Sanskrit word), ภาพลักษณ์ [phâaplák] 'image' (a Sanskrit and a Sanskrit word), มัชณิมประเทศ [mátchimpràthêet] 'India' (a Pali and a Sanskrit word). Thirdly, not only conjoining words must be pronounced with the syllable final gemination plus an intruding $/ a /$, this phenomenon occurs within the word itself, such as มุขย [múkhayá] 'the first; a chief; one principal or superior one; that 
which is in, coming from or belonging to the mouth, or face; that being at the head, or at the beginning' from Sanskrit 'mukhya' where khy is written as a combined character and no /a/ is present between $\mathrm{kh}$ and $\mathrm{y}$, รัตนา [ráttanaa] 'gem' from Pali 'ratana' and Sanskrit 'ratna', วิชญา [witchá yaa] 'a wise or learned man' from Sanskrit 'vijña', วิษณุ /wítsạnú/ 'Vishnu' but the syllable final gemination plus an intruding /a/ appears in all the preceding three words in Thai.

2.2 The compilers of the Dictionary of the Royal Institute allow too much influence of the Pali-Sanskrit pronunciation over Thai words. We all know that a long time ago the Thais changed the pronunciation of Pali-Sanskrit characters to suit their pronunciation system. For example, ค, ฆ, ช, ฌ, ฑ, ฒ, ท, ธ, พ, or ภ is no longer a voiced consonant, ฏ, ฐ, ฑ, ฒ, ณ, ษ, or ฬ is no longer a retroflex, and certain characters, such as § [t] has become [d], ต [t] has become ค [d], ป $[\mathrm{p}]$ has become บ $[\mathrm{b}]$, and a $[\mathrm{v}]^{2}$

${ }^{2} \mathrm{v}$ written as $\partial$ in Thai is a voiced labio-dental consonant in Sanskrit and it can cluster with $r$ or ฤ such as vrddhi or วฤทธิ. Since ว cannot cluster with $r$ in Thai, ว is changed to $w$ for the reason that they both have the same point of articulation at bilabial in order to suit the Thai phonological system. has become พ [ph] in certain words. Thus, it is impossible to pronounce Thai words in the same way the Hindus pronounce Pali-Sanskrit words. The Thais pronounce PaliSanskrit words according to the Thai pronunciation system. It is no use to try to retain the PaliSanskrit pronunciation. We must accept that all borrowed words from Pali or Sanskrit are now Thai words, and follow the Thai pronunciation rules.

2.3 Most Thai scholars of the Thai language ignore the importance of word rhythms or lack an understanding of the nature of the Thai language. If one surveys the textbooks on Thai grammar or on the Thai language from the Ayuddhya periods up to present, word rhythms and prosody have never been an issue, with the exception of poetry meters found in Chindamani, where again modern Thai textbooks had misinterpreted the heavy and light scheme as intended by the authors of Chindamani. It would be more appropriate to incorporate linguistic knowledge in an explanation of Thai pronunciation. Research on phonology and prosody (Gandour 1976, Haas 1964, Henderson 1973, Hiranburana 1971, Luangthongkum 1977, Luksaneeyanawin 1983, Noss 1972, Sagarik 1965, Sutadarat 1978, Thawisomboon 1955, Warotamasikkhadit 1965 , $1967,1999)$ has been conducted by Thai and foreign scholars, but 
it is ignored by the Royal Institute of Thailand. It is hard to believe that the compilers of the Dictionary of the Royal Institute have not heard about this research that clearly establishes the importance of word rhythms and prosody in the Thai language.

\section{Nature of the language}

3.1 The Thais prefer to pronounce four-syllable words as threesyllable words, a phenomenon also found in many other languages, For example, in the English words vegetable or comfortable the second syllable is omitted. In the Thai case, นนทบุรี /nonburiii/ 'the name of a province adjacent to Bangkok in the north', or อินทรธนู /inthánuu/ 'epaulet' is pronounced with three syllables instead of four.

3.2 Syllable omission or syllable contraction often appears in rapid or connected speech, for example พิษ'โลก/phitlôok/ 'the name of a province in northern Thailand' for พิษณุโลก /phitsạnúlôok/, มหา'ลัย /máhạalay/ 'university' for มหาวิทยาลัย /máhạawittháyaalay/, โรง'บาล/roopbaan/ 'hospital' for โรงพยาบาล/roonpháyaabaan/.

3.3 A silent character in a word is found in many languages including Thai such as debt where $\mathrm{b}$ is silent, salmon where 1 is silent in English. For example พราหมณ์ /phraam/ 'Brahman' where $ห$ is silent, เกียรติ /kịat/ 'honor' where ร and อิ are silent, and อินทรธนู /Pinthánuu/ where ทร are silent in Thai.

3.4 The phonological hiatus must coincide with a morpheme boundary such as รัฐวิสาหกิจ /rátwisăahàkǐt/ 'state enterprise', วิทยากร / wittháyaa/koon/ 'resource person'.

\section{Points of articulation overrule gemination rules}

Point of articulation plays a very important role in gemination rules of the Thai language. It must be noted that the following rules are very crucial to gemination rules.

4.1 If the point of articulation of the final consonant of the preceding syllable is at the same place or close to the point of articulation of the initial of the following syllable, gemination of the final consonant of the preceding word is not needed. We can see in กัมพล /kamphon/ 'woolen cloth', where the final ม $/ \mathrm{m} /$ of the preceding syllable has the same point of articulation with the initial $พ / \mathrm{ph} /$ of the following syllable, อารักขา /Raarákkhạa/ 'protect, guard', where the final ก $/ \mathrm{k} /$ of the preceding syllable has the same point of articulation with 
the initial ข $/ \mathrm{kh} /$ of the following syllable, ชัยนาท /chaynâat/ 'the name of a province north of Ayuddhya', where the point of articulation of the final $\varepsilon / y /$ of the preceding syllable is close to the initial น $/ \mathrm{n} /$ of the following syllable.

4.2 Tongue moving forward is easier than moving backward, for example ชัยนาท /chaynâat/ 'the name of a province north of Ayuddhya', and ชัยภูมิ /chayyá phuum/ 'the name of a province in the northeastern Thailand'. $\varepsilon / y /$ in ชัยนาท /chaynâat/ has the point of articulation at the palatal and น $/ \mathrm{n} /$ has the point of articulation at the alveolar which are considered very close to each other and the tongue moves forward, gemination is not needed. ชัยภูมิ /chayyáphuum/ 'the name of a province in the northeastern Thailand', where ย /y/ in ชัยภูมิ /chayyáphuum/ has the point of articulation at the palatal and 8 $/ \mathrm{ph} /$ has the point of articulation at the bilabial which is far away from the palatal, gemination with an intruding $/ a /$ is needed in this case.
4.3 When the two points of articulation are far apart, the tongue must be placed at a neutral position before pronouncing the next syllable. For example สัปดาห์ /sappạdaa/ "week"3. ป/p/ has the point of articulation at the bilabial which is far front and ด /d/ has the point of articulation at the alveolar which is further in the mouth. The tongue must be placed at a neutral position $/ \mathrm{a} /$ before pronouncing the following syllable beginning with $/ \mathrm{d} /$. Thus, gemination of the final $/ \mathrm{p} /$ of the preceding syllable is needed.

\section{Gemination rules}

5.1 Gemination rules will never apply in the following cases:

\subsubsection{When two of the same consonants stand next to each other, for example สัมมา /sămmaa/ 'rightly', อัสสุ /Ràtsụ/ 'tears'.}

\footnotetext{
${ }^{3}$ Some traditional Thai grammarians who cling to Pali-Sanskrit pronunciation often tell Thai students to pronounce this word as /sàpdaa/ because it comes from สัปต /sapta/ 'seven' in Sanskrit and no gemination with an intruding $\mathrm{la} /$ is present in Sanskrit.
} 
5.1.2 When a consonant of the same series ${ }^{4}$ stands in front of another consonant of the same series, for example กัญชา / kanchaa/ 'marijuana', สิทธิ/sìt/ 'right(s), privilege(s)'.

5.1.3 When $y$ stands in front of ฐ, for example เศรษฐี /sẹtthii// 'a millionaire', อธิษฐาน/Ràthîtthăan// 'to make a wish, to pray'.

5.1.4 When $s / \mathrm{y} /$ stands before any consonant, for example กังวล /kanwon/ 'worry' สิงหรา/sīghạaa/ 'lioness'.

${ }^{4}$ There are five series of consonant and several nonseries consonants in the Thai as follows:

Series Consonants

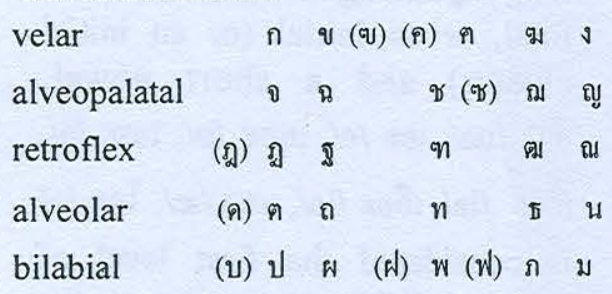

Nonseries Consonants

$$
\begin{array}{lllllll}
\text { ย } & \text { ร } & \text { ล } & \text { ว } & & & \\
\text { ศ } & \text { ษ } & \text { ส } & \text { ห } & \text { พ } & \text { (อ) } & \text { (ฮ) }
\end{array}
$$

The characters in parentheses are Thai characters added to the Sanskrit characters.
5.1.5 When น $/ \mathrm{n} /$ stands before any consonant, except ก $/ \mathrm{k} /$ and น $/ \mathrm{n} /{ }^{5}$, for example กันยา /kanyaa/ 'girl', ชนม /chonmá/ 'age', สันสกฤต /sănsàkrìt/ 'Sanskrit'.

5.2 Gemination within a word. Gemination rules can be established for multi-syllable words as follows:

5.2.1 If the preceding part of a word ends with a nonseries consonant and the second part of it begins with a series consonant or a nonseries consonant, the final of the preceding part of the word must be geminated and an /a/ is inserted after it, for example บรรยาย = บรร + ระยาย/banráyaay/ 'lecture', วาสนา = วาส + สะนา /wâatsànǎa/ 'fate, luck', อลเวง = อล+ละเวง / ponláween/ 'confusing, chaotic', อัศว = อัศ +

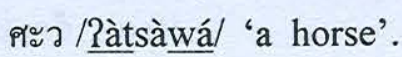

${ }^{5}$ ชนนี /chonnánii/ is pronounced with a gemination of $น / \mathrm{n} /$ plus an intruding vowel $/ \mathrm{a} /$. ทินกร /thinnákoon/ is also pronounced with a gemination of $น / \mathrm{k} /$ plus an intruding vowel /a/. 
5.2.2 If the preceding part of a word ends with a series consonant and the second part of it begins with a nonseries consonant, the final of the preceding part of the word must be geminated and an /a/ is inserted after it, for example อุณหิส = อุณ +

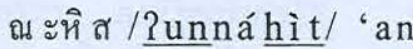
ornament or decoration for the head, a crown, a turban, a diadem, a coronet, a chaplet, or a wreath', อุปโลกน์ $=$ อุป +

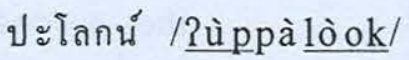
'temporarily appointed by consensus'

5.2.3 If the preceding part of a word ends with a series consonant and the second part of it begins with a consonant of different series, the final of the preceding part of the word must be geminated and an la/ is inserted after it, for example วัฒนา = วัฒ + ฒะนา /wátthánaa/ 'grow', วิชนี = วิช + ชะนี /wítchánii/ 'fan', สักตะ $=$ สัก + กะตะ /sakkạta/ 'Sanskrit', อุปถัมภ์ $=$ อุป + ปะถัมภ์ /?ùppàthăm/ 'to patronize, to support, to assist'.
5.3 Gemination rules for conjoining words. Gemination rules for conjoining words follow the same rules for a single word, but 5.1 .5 is ignored, for example ชนบท = ชน + นะบท /chonnábòt/ 'rural area'.

The gemination rules for conjoining words are overruled by three-syllable word rhythms in 7 . If the conjoining words contains three syllables, gemination rules 5.2 will be ignored, for example อุณหภูมิ / ?unhàphuum/ 'temperature', not /Punnáhàphuum/, เพชรบุรี /phétburii/ 'the name of a province west of Bangkok near Ratburi', ราชบุรี /râatburii/ 'the name of a province west of Bangkok and east of Petburi'.

\section{Syllable structure of Thai words}

Syllable structure of Thai words can be classified into eight levels of syllable structure ranging from the heaviest to the lightest.

6.1 A syllable composed of an initial (or an initial cluster) and a long diphthong with or without a final, or an initial (or an initial cluster) and a short vowel, อัวะ /ua/, เอะ /e/, เออะ /ə/, เอาะ /o/, เอียะ /ia/, เอือะ /ia/, แอะ /æ/, โอะ /o/ is considered the first level of heavy syllable structure or the heaviest syllable structure, for example เตรียมอุดม /triam?udom/ 
'preuniversity', เพลียใจ /phliacay/

'to be exhausted at heart' เหมาะเจาะ /mòc / ' 'fitting, suitable', โป๊ะเชะ/póché/ 'excellent'.

6.2 A syllable composed of an initial (or an initial cluster) and a long vowel with a sonorant final is considered the second level of heavy syllable structure, for example ช้องนางรำ /chóonnaanram/ 'the telegraph plant, whose small leaflets make curious jerky movements', วานซืน /waansiin/ 'the day before yesterday'.

6.3 A syllable composed of an initial (or an initial cluster) and a long vowel with a stop final is considered the third level of heavy syllable structure, for example ราบคาบ /râapkhâap/ 'to have been completely subdued', โลกประทีป /lôokpràthîip/ 'the world's radiant rays--i.e. a title for the Buddha', โสตประสาท/sòot_pràsàat/ 'the auditory nerve'.

6.4 A syllable composed of an initial (or an initial cluster) and a long vowel without a final is considered the fourth level of heavy syllable, for example กากี /kaakii/ 'a female crow; khaki', บูชา /buuchaa/ 'to pay homage to, to adore'.

6.5 A syllable composed of an initial (or an initial cluster) and a short vowel with a sonorant final is considered the fifth level of heavy syllable, for example จัณฑาล /canthan/ 'a rafter', นัยนา /nayyanaa/ 'eye', สำคัญ /samkhan/ 'important', เอาฬาร /?awlaan/ 'magnificent, large'.

6.6 A syllable composed of an initial (or an initial cluster) and a short vowel with a stop final is considered the sixth level of heavy syllable, for example กษมล /katsa mon/ 'foul, dirty', อิจฉา / Ritchạa/ 'to envy'.

6.7 A syllable composed of an initial (or an initial cluster) and a short vowel which is not a blank or อะ $/ a /$, อัวะ /ua/, เอะ $/ e /$, เออะ $/ a /$, เอาะ $/ \mathrm{s} /$, เอียะ $/ \mathrm{ia} /$, เอือะ $/ \mathrm{ia} /$, แอะ $/ æ /$, โอะ $/ 0 /$ without a final is considered the seventh level of heavy syllable structure, for example จิระ /çrá/ 'lasting a long time, lengthy', พิริยะ /phíriyá/ 'strength, vigor'.

6.8 A syllable composed of an initial (or an initial cluster) and a vowel $/ \mathrm{a} /$ is considered the eighth level of heavy syllable structure or the lightest syllable structure of all, for example จะ/ca/ 'will', ชะนี/chánii/ 'gibbon'.

A syllable containing a vowel $/ \mathrm{a} /$ always becomes a light syllable. 
The relative degree of light/heavy syllable is applied in the word of two syllables or more. If a lower level syllable stands next to a higher level syllable, by applying to the leftmost of the word first, the lower level syllable becomes a light syllable and the other syllable becomes a heavy syllable. For example, มโน/mánoo/ 'mind, heart', ตะแบก /tàbæ̀æk/ 'a kind of hard wood tree', where the second syllable will be a heavy syllable, โมระ /moora' 'a peacock' ภาพลักษณ์ /phâaplák/ 'image', where the first syllable will be a heavy syllable, กริยา /kàríyaa/ 'verb', สุรสีห์ /sùrášii/ 'lion', where the second syllable is a light syllable and the last syllable of a word is always a heavy syllable. If the two syllables are of the same level, both can be light syllables if containing a short vowel according to $6.5,6.6,6.7$ or 6.8 , for example มะระ /márá/ 'bitter melon', สระ /sạrạ/ 'vowel', กิ๊กกั๊ก /kikkkák/ 'to giggle'. or both can be heavy syllables if containing a long vowel. For example, สีกา /ṣiikaa/ 'woman', เฮฮา /heehaa/ 'the sound of hearty laughter'. This relative degree of light/heavy syllable will be applied in 7 below.

The Thais should be proud of their forefathers' ingenuity in devising the combined vowel forms for certain short vowels, อัวะ /ua/, เอะ /e/, เอาะ / /, เอียะ/ia/, เอือะ / $\mathrm{ia} /$, แอะ /æ/, and โอะ /o/ to signify a heavy syllable in contrast to simple short vowels, อะ /a/, อิ/i/, อึ/il, อุ/u/, โอะ/o/ to signify a light syllable. Thai poetry in the Ayuddhya period such as Anirut Kham Chan. Samutthrakhot Kham Chan, Suea
Kho Kham Chan follows the above light/ heavy scheme.

\section{Word rhythms}

7.1 One-syllable words. Prominence must be placed on one-syllable words, no matter whether it is a light or heavy syllable, with exceptions of a preverb such as จะ /ca/ 'will', ก็ $/ \mathrm{k} \hat{\mathrm{j} /}$ 'consequently, quite', etc., a one-syllable pronoun such as ฉัน /chán/ 'I', ผม /phọm/ 'I', a noun functioning as a relator such as นอก /nôok/ 'outside', ใน /nay/ 'inside', a final particle such as คะ /khá/ 'question final particle for a female speaker, or a final particle after นะ /ná/ 'an insist final particle', ครับ /khráp/ 'a final particle for a male speaker'.

7.2 Two-syllable words. There are two types of two-syllable words.

7.2.1 When the first syllable of the word is a light syllable, the second syllable takes prominence, no matter whether it is a light or heavy syllable, for example, มณี /mánii/ 'ruby', บัณฑิต /bandit/ 'a degree graduate', ศึกษา/s̀̀ksăa/ 'study'. If both syllables are a light syllable, the last syllable takes prominence, for 
example ชนะ /cháná/

'to win', ปุระ /pùrá/

'fort, town'. If both open syllables are a heavy syllable of the same level, the last syllable takes prominence, for example อีกา /Riikaa/ 'crow', เวลา /weelaa/ 'time'. If the first syllable is an open long vowel such as, อีกา /Riikaa/ 'crow', and เวลา /weelaa/ 'time', the long vowel will be shortened to /i/ and /e/ respectively as //ikaa/ and /welaa/. The shortened vowel must be pronounced without a glottal stop at the syllable end.

7.2.2 When the first syllable and the second syllable are a heavy syllable of the same level, but not an open syllable, both syllables take prominence, for example ยืคยาด/ŷittyâat/ 'taking a long time', สูงส่ง /sǔunsòn/ 'of high civil dignity, stateliness, having majestic grandeur', เหมาะเจาะ /mòcว̀/ 'fitting, suitable, elegant, appropriate, proper for the occasion'.

7.3 Three-syllable words. The most favorite word pattern for the Thais is the three-syllable word pattern. If a conjoining word can be pronounced with three syllables, the gemination rules in
5.2 will be ignored. There are three types of three-syllable words.

7.3.1 The most popular pattern of the three-syllable words contains prominence on the first syllable and the last syllable. If the second syllable is a light syllable and the first syllable does not contain the syllable อ $/ \mathrm{a} /$, prominence will be placed on the first and the last syllable, for example กริยา /kàríyaa/ 'verb', เพชรเกษม /phétkàsěem/ 'the name of the highway from Bangkok to the south', เพชรบุรี /phét bùrii/ 'the name of a province west of Bangkok', ภาพยนตร์ /phâappháyon/ 'movie', มะตะบะ/mátabà/ 'a kind of Muslim food'. มาลินี /maalinii/ 'a female florist', ราชบุรี /râatbùrii/ 'a province west of Bangkok', วาสนา /wâatsànăa/ 'fortune, fate, luck', สาวิตรี /săawittrii/ 'a Vedic poem of praise and prayer to the Sun', สุริยะ/sùriyá/ 'the sun', อิทธิพล / Titthîphon/ 'influence, power'.

7.3.2 If the first syllable of the three-syllable words is e /a/ preceding a light 
syllable, prominence will be placed on the second and the third syllable, for example อธิการ /Ràthikkaan/ 'abbot', อธิบาย /Ràthîbaay/ 'to explain'.

7.3.3 If the first syllable of the three-syllable words is a light syllable and the second syllable is a heavy syllable, prominence is placed on the second and the last syllable, for example กุฎาธาร /kùdaathaan/ 'top', ประจวบเหมาะ /pràcùapmò/ 'to be coincident', พยาบาล /pháyaabaan/ 'to nurse' พิชิตมาร /phichitmaan/ 'one who conquered Mara, i.e. the Buddha', สุมาลี /sùmaalii/ 'flower', มโนมัย /mánoomay/ 'mental, spiritual', สมานฉันท์ /sàmăanchăn/ 'agreement, congruence', สังฆาณัติ /sânkhaanát/ 'the command of the Patriarch to Bhuddist monks'; อุบัติเหตุ /Pùbàthèet/ 'accident"6.

7.4 Four-syllable words. There are four types of four-syllable words as follows:

${ }^{6}$ Some people will pronounce it as /Rùbàttihèet/ as a four syllable word.
7.4.1 The popular pattern for four-syllable words is to place prominence on the second and the last syllable. If the first and the third syllable is a light syllable, or the second syllable is a heavy syllable, prominence is placed on the second and the last syllable, for example ตวักตะบวย /tàwàktàbuay/ 'some nonsense matter ปทุมธานี /pathumthaanii/ 'the name of a province adjacent to Bangkok in the north', พนัสนิคม /phánátnikhom/ 'a town in Chonburi', มัชฌิมประเทศ /mátchimpràthêet/ 'India', สภาวการณ์ /sàphaawákaan/ 'situation', สุพรรณบุรี /suphanburii// 'the name of a province west of Bangkok', เอร็ดอร่อย /Ràrèt?àròy/ 'delicious'.

7.4.2 If the first and the third syllable of the foursyllable word are a light syllable, prominence is placed on the first, the third, and the last syllable. It is possible that there may be a light to heavy syllable shift occurring within the word, for example เจตนารมย์ /ceettạnaarom/ 'intention, 
purpose', รัฐมนตรี

/rátthàmontrii/ 'cabinet minister', ราชบัณฑิต /râatchábandit/ 'member of the Royal Academy', วิทยาเขต /wittháyaakhêet/

'campus', สัมปชัญญะ

/ $\mathrm{s} \mathrm{a}^{2} \mathrm{~m}$ pà $\mathrm{ch}$ any $\mathrm{a}^{\prime}$ /

'conciousness'. อิริยาบถ

/ iríyaabòt/ 'movement, action'.

7.4.3 If the first and the second syllable of the foursyllable word are a heavy syllable, prominence is placed on the first, the second and the last syllable, for example กัตติกมาส /kattikkamaat/ 'the twelfth lunar month which is about November', ไพศาขมาส /phaysăakhàmâat/ 'the sixth Thai lunar month corresponding to April and May', โมฆียกรรม /mookhiiyák kam/ 'a disannulled legal act'.

7.4.4 If the second and the third syllable of the foursyllable word are a light syllable, prominence is placed on the first and the last syllable, for example โบกขรพรรษ /bôokkhàráphát/ 'a shower of rain that wets only those who want to be wet as compared to drops of rain collected on lotus leaves', วัฒนธรรม /wátthánátham/ 'culture', วิศวกร /wît sàwákoon/ 'an engineer'.

7.5 Words of more than four syllables are usually composed of words of one, two, or three syllables conjoining together. One should be. careful that hiatus should coincide with a morpheme boundary.

\section{Conclusion}

It is evident that word rhythms can overrule syllable structure in some cases because the pattern prominence-lightprominence or light-prominenceprominence dominates the pronunciation pattern where gemination rules can be ignored. The gemination rule provided on page (7) of the Dictionary of the Royal Institute of B.E. 2525 should be revised because the statement is incorrect in many respects. It is also important to note that the last syllable of Thai words always takes prominence, except in preverbs, onesyllable pronouns, nouns functioning as a relator, and final particles. Syllable omission or syllable contraction often occurs in rapid or connected speech. 


\section{References}

Bee, Peter. 1975. Restricted Phonology in Certain Thai Linker-Syllables. Studies in Tai Linguistics in Honor of William $J$. Gedney, ed. by Jimmy G. Harris and James R. Chamberlain. Bangkok, Central Institute of English Language, Office of University Affairs.

Gandour, Jackson T. 1976. A reanalysis of some phonological rules in Thai. Tai Linguistics in Honor of Fang-Kuei $L i$, ed. by Thomas Gething, Jimmy G. Harris, and Pranee Kullavanijaya, pp. 47-61. Bangkok, Chulalongkorn University Press.

Haas, Mary R. 1964. Thai-English Dictionary. Stanford, CA, Stanford University Press.

Henderson, Eugénie J.A. 1949. Prosodies in Siamese: a study in synthesis. Asia Major (New Series) 1.2, pp. 189-215.

Hiranburana, S. 1971. The Role of Accent in Thai Grammar. Unpublished Ph.D. dissertation. London, London University.

Luangthongkum, Theraphan. 1977. Rhythm in Thai. Unpublished Ph.D. dissertation. Edinburgh, University of Edinburgh.

Luksaneeyanawin, Sudaporn. 1983. Intonation in Thai. Unpublished $\mathrm{Ph} . \mathrm{D}$. dissertation. Edinbugh, University of Edinburgh.

Noss, Richard B. 1972. Rhythm in Thai. Tai Phonetics and Phonology, ed. by J.G. Harris and R.B. Noss. Bangkok, Central Institute of English Language.

Peyasantiwong, Patcharin. 1986. Stress in Thai. Papers from a Conference on Thai Studies in Honor of William J. Gedney, ed. by Robert J. Bickner, Thomas J. Hudak and Patcharin Peyasantiwong. Ann Arbor, MI, The University of Michigan.

Phasit Chit Phasa (pseudonym). 1998. Who causes the confusion in pronouncing Thai words? Art and Culture, 19.12, pp. 66-67. (in Thai).
Sagarik, P. 1965. An Analysis of the Elements in Thai that Correspond to Basic Intonation Patterns of English. Unpublished Ed.D. dissertation. New York, NY, Columbia University.

Sutadarat, Suntana Gungsadan. 1978. A Phonological Description of Standard Thai. Unpublished Ph.D. dissertation. Madison, The University of Wisconsin-Madison.

Thawisomboon, S. 1955. Syllable Junctures within Stress Groups in Spoken Thai. Unpublished MA thesis. London, London University. Warotamasikkhadit, Udom. 1965. The Phonological Grammar of Thai. Unpublished manuscripts presented to SEATO. Cambridge, Massachusetts Institute of Technology.

1967. Stress and tone rules in Thai, Papers of the CIC Far Eastern Language Institute: The University of Minnesota, 1966 and The University of Michigan, 1967, pp. 169-175.

1967. Some phonological rules in Standard Thai, The Journal of American Oriental Society 87.4 , pp. 541-574. 1999. Rhythm in Thai. Unpublished manuscripts presented to the Committee for Revising the Dictionary of the Royal Institute of B.E. 2525. (in Thai) 